\title{
CRIMINAL INVESTIGATION \\ IN ALLEN ESKENS' NOVEL THE LIFE WE BURY
}

\author{
Suci Amalia, Safitri Hariani \\ Faculty of Literature, Universitas Islam Sumatera Utara, Medan \\ e-mail: suci23303@gmail.com
}

\begin{abstract}
This research is concerned with the criminal investigation done by the protagonist by the name of Joe Talbert in Allen Eskens's novel entitled The Life We Bury. It aims to reveal Joe Talbert's investigation on a criminal case to uncover the truth. The novel, books, journals and website relating to the criminal case are used as source of data. The data is analyzed by classifying the obtained data in two sub chapters related to the research problems of this study. The writers adopt the theory from Taber K (2006). They are the protagonist's way in doing his criminal investigation and the results of his criminal investigation. This research uses descriptive qualitative method in analyzing the data. The finding shows that firstly there are two ways in getting information on the criminal investigation, such as doing inspection in the court of law and doing interview, and secondly that the results of his criminal investigation shows the truth of Carl's real life and the real murderer.
\end{abstract}

Keywords: Protagonist, Criminal investigation, Information, Inspection, Interview

\section{Introduction}

The Ministry of National Education (2008: 557) gave the definition of crime as a misconduct violating the law, behavior that is contrary to the values and norms which has been ratified by written law. This definition shows that crime is an act that violates the law and norms that have prevailed in society. The law has also been written and has been ratified. "But people who had committed unthinkable crimes were also called heroes" (Gibbon. 2009) in Selian, Suhadi, \& Manugeren (2017).

The Life We Bury is Allen's first novel. The story is about a college student, Joe Talbert. He is on deadline to complete a writing assignment for an English class. His task is to interview a stranger and write a brief biography. So Joe interviews an old man, Carl Iverson, a cruel criminal. From the beginning they met, Carl said that he does not want to judge someone before knowing the whole story of his life. Carl's words make Joe even more curious and finally Joe really finds out about the old man's life. At first, he interviews Carl only for college assignment but the longer he makes the assignment, the more he gets information about Carl's life. He realizes that it is his duty to uncover all the secrets that Carl and the people around him has covered up. Joe wants Carl to be known not as a criminal but as a hero.

This research is concerned with the criminal investigation of the young man who uncovers the truth. Protagonist's investigation is very necessary in solving a problem but it must be suitable with the procedures set in order to achieve the goal. And it becomes interesting for the researcher to make an analysis on it because it will show how to do the investigation in a criminal case to uncover the truth. Furthermore, protagonist's 
investigation is the most often action which are shown in the novel so that the writers decide to analyze the protagonist's criminal investigation.

\section{Literature Review}

Criminal is an offense law, namely opposite or contradictory events with lega principles that live in human life beliefs and apart from the law (G.W. Bawengan, 1974: 22). This definition explains that criminal is a person who commits a crime that violates the law and basically every human being knows that crime is wrong.

Bonger (1982: 21-24) in his book Introduction to criminology, defines that crime that is as immoral and anti-social actions, which are not desired by the people, and consciously opposed by the government (state). Government will put the doer of the crime by giving suffering in the form of punishment or action. This definition explains that crime is an act that is hated by society and also by the State. Criminals can be punished by the government. Crime is an act that violates the rules / law where the community lives and harms society others. Crime is included in all types of public violations (Suhartono W. Pranoto, 2008: 39). This definition shows that it is an act which is wrong according to human and state views because it harms others.

According to Kartono (1999: 130-136), types of crime can be divided into: types of crime in general (Robbery, Frauds, and Theft and violations). Crime is laso classified based on the way the crime is committed. They are fulfilled by using tools, without using tools, and recidivist. While based on the object the criminal attacks, crime is divided into 1. Economic crimes: fraud, embezzlement, smuggling, trafficking of prohibited goods, bribery and bribery to obtain certain monopolies. 2. Political crime and defense: violations of public order, betrayal, sales of state secrets to foreign agents in the interests of subversion, disruption, crimes against state security and state power, insulting the dignity of state leaders, collaboration with enemies, etc. 3. Decency crime: sex offenses, rape, slander. 4. Crime against people's souls and property.

This research adopts Taber's theory (2006) because it is coherent with the analysis. Taber (2006) points out in his book, Beyond Constructivism, people constantly construct knowledge, and, in our daily lives, we function in a perpetual state of assessing the information that is presented to us. Interpreting the perceptions of what we see and what we hear allows us reach conclusions about the world around us (Taber, 2006). This definition explains that some people are critically analytical and want to see evidence to confirm their beliefs, while others are prepared to accept information at face value until they are presented facts that disprove their previously held beliefs. Either strategy is generally acceptable for ordinary people in their everyday lives. This theory shows how to collect the data from investigations, such as searching for witnesses, finding out information through witnesses, collecting traces left at the scene of crime, expert reports, asking suspects and searching for evidence by reading archival records that have been examined previously.

As written above that government will give punishment to the criminals. However, before the government gives punishment to the criminals, there must be an investigation to prove that he or she is really the criminal and deserves a punishment. Based on the Law of the Republic of Indonesia Number 8 of 1981 concerning Criminal Procedure Law, "Investigation is a series of investigator's actions in terms of and according to the method stipulated in the law to find and collect evidence that with evidence makes it clear about the crime that occurred and to find the suspect". This definition shows that the investigation is looking for evidence related to the incident as 
strong evidence to find a suspect. Based on the juridical definition, several statutory provisions mention that the notion of investigation includes the Criminal Procedure Code and Law Number 2 of 2002 concerning the Police of the Republic of Indonesia. Article 1 number 13 Law Th. 2002 No. 2 concerning the Republic of Indonesia National Police and Article 1 point 2 of the Criminal Procedure Code provides the same understanding of the actions of investigations, stated that: "Investigation is a series of investigative actions in terms of and according to the law stipulated to find and collect evidence which makes clear about the crime that occurred and to find the suspect". This definition explains that the evidence collected can be a reference to arrest suspects.

R. Soesilo (1980) also states that investigations meant finding traces, in this case traces of crime, which means that after the traces were found and collected, the crime would be revealed. This definition shows that the investigation is to find evidence of the former occurrence of the case then collect it and reveal the perpetrators of the crime.

Criminal investigation is, in essence, the process of answering questions as to if, how, where, when, why, and by whom a crime was committed (Greenwood et.al., 1977). This definition shows that investigator must collect the data from the clues which have been investigated. Those clues must be coherent with the event. The official purpose of criminal investigation is to retrieve information that can be used as evidence in court (Bring, et.al., 1999; Van Koppen \& Penrod, 2003). It means that the data which has been collected must be proven correct because the investigator is responsible for his research so that the data can be used as evidence in court. Criminal investigation has been likened to a hypothesis-testing process (Wagenaar, et.al., 1993). It shows that one or more tentative hypotheses are formed on the basis of the initially available information concerning a crime. Such hypotheses include assumptions about likely perpetrators, modes of conduct, and motives behind the offense.

\section{Research Method}

This study applies qualitative research. In qualitative research, the researcher addresses research problems where the variables are unknown and require exploration (Creswell, 2012). Key concept, idea or process studied in this type of research is a central phenomenon. This type of research views something as a central phenomenon that is required to be explored and understood (Creswell, 2012).

\section{Discussion}

\subsection{The Ways of Collecting the Information of His Criminal Investigation 4.1.1 Doing Inspection in the Court of Law}

Based on the story in the novel, Joe Talbert collects information through articles in the newspaper which he finds in the court archives. In the article, it is written about the incident that killed a fourteen year old child, Crystal Hagen. It can be seen in the following quotation:

"I printed a copy of the page and then spooled through the micro film to the next day's edition. In a follow up article the police confirmed that the body found the day before had been identified as fourteen years old Crystal Hagen. The body had been badly burned, and authorities suspected that she had already been dead when the fire was set. The burned out shed was located next door to the house where Crystal had live with her mother, Danielle Hagen; her stepfather, Douglas Lockwood; her stepbrother, Dan Lockwood. Crystal's mother, Danielle, told reporters that they had noticed 
that Crystal was missing shortly after word spread that a body had been discovered in the debris of the shed. Crystal was positively identified as the deceased using dental records. The article ended with the note that thirty two years old Carl Iverson had been taken into custody for questioning. Iverson lived next door to Crystal Hagen and owned the shed where Hagen's body was found". (Eskens, 2014: 33)

The above quotation explains that Joe has printed a page from the article. In the article, it was written that Crystal Hagen had been burned in the warehouse. The warehouse is owned by Carl Iverson, which is next to Crystal's house. In that article the name of the family member who lives with Crystal is also written. At the scene found the items which belonging to Crystal Hagen that is not caught in fire. There is a fake nail that detached from her original nail and it has been kept by the court as evidence. Joe's friend, Lila, helps him check the archives, as quoted in the following quotation:

"Crystal fought for her life. We know this because one of her false fingernails broke off during the struggle. That fingernail was found on the steps leading out of Carl Iverson's house. It fell there as Carl Iverson dragged her body to his tool shed. He dumped her body onto the floor of that shed as if she were just a piece of garbage, then try to hide his crime from the world, he set his shed on fire, believing that the heat and the flames would destroy the evidence of what he had done. After he touched a match to that old shed, he went back in his house and drank from a bottle of whiskey until he passed out." (Eskens, 2014: 79)

Related to the quotation above, it tells that Crystal's death is not only burnt but she is tortured before. The strong evidence shows Crystal's fake nails were left on the steps in Carl Iverson's warehouse. It means that she is tortured and she tries to defend her life by fighting the murderer, but she loses and Carl kills her. Carl removes evidence by burning Crystal and then he leaves the warehouse. In that archives also finds Crystal's diary which she tells a few pages about Carl, as described in the following quotation:

"Lila looked at me like I was an idiot. In my defense, I was still groggy with sleep. She turned back to her train of thought. " The diary starts out in May of 1980," Lila said, lying her notes on the coffee table in front of me. "The first few months are full of normal teenage crap. She's excited about starting high school one day and scared about it the next. For the most part she's a happy kid. She has fifteen entire about Carl between June and September, usually referring to him as the pervert next door or creepy Carl." (Eskens, 2014: 105)

The quotation above explains that Crystal likes to write about her life story in a dairy book. Lila thinks Crystal is a cheerful girl because Crystal writes her happy story, but after seeing the next page, Crystal writes that she is worried because for several days, Carl seems to be stalking her and she writes Carl is a pervert neighbor. Crystal's writing looks strange on a few pages. She uses a numeric code in her story.

"October $29-6,1,19,10,22,18,3,17,3,25,16,19,10,22,18,6,13$, $26,17,3$. Mrs. Tate said so. She said that the age difference means he'll go to prison for sure. It stops today. I am so happy." (Eskens, 2014: 108) 
The quotation above shows that Crystal is afraid if someone reads her writing, so she uses part of her writing with a numeric code. He writes about someone older than her. This person has insulted her and he has to go to prison. When Carl is trial thirty years ago, these codes have not been solved yet. Joe's brother, Jeremy, help him to solve the code. It turns out that the codes are taken from a song that Crystal learns in her school.

" October 29-It's rape. DJ is raping me. Mrs. Tate said so. She said that the age difference means he'll go to prison for sure. It stops today. I am so happy." (Eskens, 2014: 184)

The quotation above explains that code has been solved by Jeremy. Crystal Hagen starts using her code in September 1980. It was her freshman year of high school when she is taking a typing class with Andy Fisher, her ex boyfriend. The code is taken by the quick fox brown jumps over the lazy dog. It is sentence in keyboarding class and it has every letter of the alphabet in it. Crystal writes that the one who rapes her is a DJ. It is an extension of Douglas Lockwood. He is Crystal's stepfather. Crystal wants to end it by reporting him to the police and he will go to prison.

\subsubsection{Doing Interview}

The other way how Joe gets information of his criminal investigation is from doing interview to some people that related to Carl's case. The first person he interviews is the old man who has been accused of being rapist and murderer of Crystal Hagen. The man is Carl Iverson. He is a dying veteran and a convicted murderer. With only a few months to live, Carl has been medically parole after spending thirty years in prison for the crimes of rape and murder. Now, he is in an old folk's home. Joe meets him there and interviews him. Carl claims that he does not kill Crystal, but Joe does not believe it. Carl tells Joenotto judge someone from his cover. It is emphasized in the line, "That you understand how wrong it is to judge someone before you know their whole story." (Eskens, 2014: 45)

Carl wants Joe to believe for what he said to him. People can say everything about him even they do not know about his life, so they just conclude for what they see. The one who believe that Carl does not murder the girl is his best friend, Virgil. Then Joe interviews Virgil to get more information about Carl.

Carl Iverson is a hero-a true god-damned hero. He was willing to lay down his life for me. He's not a rapist. He didn't kill that girl.

(Eskens, 2014: 90)

The quotation above informs that Virgil really knows about Carl's story. Carl is a good man. Carl Iverson saves Virgil's life when they fight in Vietnam. Joe begins to believe if Carl is not guilty, but he needs strong evidence to be used as evidence in the court. He searches for additional information by interviewing Crystal's ex-boyfriend, Andrew. Andrew is the only person who last sees Crystal when she is alive. Joe gets information from Andrew that Crystal hates his father, as described in the following quotation:

"She hated him," he said. "He used to belittle her using lines from the bible. Most of the time, she had no idea what he was saying. One time, he told her that she should be thankful that he was not Jephthah. We looked that one up." (Eskens, 2014: 154) 
It explains that Crystal hates her step-father. Crystal tells Andrew that her stepfather is rude to her. But Andrew underestimates her by quoting a verse in the Bible. He uses many reasons to defend her stepfather. Andrew tells Crystal that she should be lucky that her stepfather is not Jephthah, he is a judge of is real who sacrified his daughter in consequence of a vow that if victorious in battle he will sacrifice the first living thing that meets him on his return.

\subsection{The Results of His Criminal Investigation 4.2.1 Revealing Carl's Life Story}

After gathering some information, Joe has finds the results of his Criminal Investigation. He finds strong evidence to prove at the trial. The information that he had collected before is not in vain. Joe also gets information about Carl's life through Virgil. He says that they are soldiers, as indicated below:

I met Carl Iverson in Vietnam in 1967. We were dumb kids fresh out of boot camp. Did a tour in the jungle with him- doing things, seeing things that you just can't explain to people who weren't there. (Eskens, 2014: 86)

The quotation above informs that Virgil met Carl in Vietnam when they are assigned to the same place and in that tour he comes to know Carl well enough. Carl is good man. He is a soldier who is assigned to fight in Vietnam. He has already felt the cruelty of life. When the war takes place, he only know he is killed. He is required to exclude innocent people from being killed viciously. He includes killing innocent people because he obeys the orders of his sergeant. Because of his guilt, he hopes to die on the battlefield. As verified below:

The crack in Carl Iverson's world, one that would cause him to want to die in Vietnam, began on a peaceful winter morning in early February 1968. Light clouds covered the horizon in advance of the sunrise, the stillness of surrounding valley belying the ugliness of coming events. The brilliance of that sky reminded Carl of a morning he'd spent at his grandfather's cabin in the north woods, a morning long ago when the nation of killing or being killed held no place in Carl's life. The fighting had weighed Carl down, him feel old. (Eskens, 2014: 137)

The quotation shows that Carl is almost desperate but he is confused about how to end everything. He hopes to die soon in his war in Vietnam. Being a soldier is a tough task, especially the sergeant who wants him to be a brutal person. The sergeant rules something they hate, which is killing people who are not wrong to expand their protection area. But Carl does not rape and murder Crystal Hagen. He surrenders to receive punishment. It is emphasized in the following quotation:

"I had no right to take Gibb's life," Carl said. "He had a wife and two kids back in the states, and I murdered him. I killed a great many men in Vietnam...... great many, but they were soldiers. They were the enemy. I was doing my job. I murdered Gibbs, and as far as I'm concerned I murdered that girl in Oxbow. I didn't pull the knife across her throat, but I murdered her just the same. When they arrested me for the murderer of Crystal Hagen... well, I think part of me figured it was time to pay my debt. Before I went to prison, I used to fall asleep every night seeing the poor Vietnamese girl. I would see her fingers begging me to come to her, to 
help her. No matter how much whiskey I drank, I could never dim that memory." (Eskens, 2014: 193)

The quotation above shows that Carl helps a girl who is almost raped by his cruel sergeant. Carl does not want this bad thing will happen again. He has seen his sergeant raping and killing a girl in Vietnam, but he can only be quiet because he does not dare to fight his sergeant but for the last time, he would not only be silent at the sergeant's cruelty. He kills his sergeant and save the girl when he is at Oxbow. But still he feels guilty about the incident in Vietnam.

\subsubsection{Revealing the Real Murderer}

After doing the investigation, Joe not only reveals about Carl's story, but he also find the rapist and the real murderer. He is Crystal's stepfather, Douglas Lockwood. Joe meets Douglas and asks him to confess his crime before he takes him to the police station.

"I broke her code, I know she was writing about you. You were the man making her do those things. You were raping your step daughter. I know you did it. I just wanted to give you the chance to explain why before I go to the cops." (Eskens, 2014: 209)

The quotation above explains that Joe meets Douglas and asks him to confess his crime before he takes him to the police station. Joe asks Douglas the reason why he rapes and murders his step daughter. Joe tells him that he knows about it from the code in Crystal's diary. She is writing about Douglas by using the code and Joe can break the code. Joe feels the law is unfair so far. Douglas should has been punished in prison instead of Carl. Even if this is the case of 30 years ago, the law must continue it. Carl Iverson is innocent and the real villain must accept his punishment. Joe puts all the evidence in the court and he succeeds. The results of his criminal investigation are not in vain. He is found not guilty, "Carl Iverson is completely and officially innocent," Sanden said, beaming with delight." (Eskens, 2014: 295)

The quotation above informs that Carl is found not guilty. His name is clear of Criminal records. He should be remembered as a hero, and not a murderer. It is because Carl is a good person. He is not a villain. He is a soldier who had saved others life. That is why he is a person who cannot see the crime happen in front of his eyes

\section{Conclusion}

It is found that Joe does various ways to find out the information to uncover the truth of the Carl Iverson's case. The evidence that has been collected shows that Carl is not guilty. The real rapist and murderer is Crystal Hagen's stepfather, Douglas Lockwood, and. Joe has known stories from Carl's past. He is a soldier who has saved the lives of others but he surrenders accused of being guilty because he feels he deserves to be punished for his past sins.

\section{References}

A, Bonger W. (1982). Pengantar Tentang Kriminologi, Ghalia Indonesia, Jakarta. Bawengan, G.W. (1974). Teknik Interogasi dan ksus-kasus kriminil. Pradnya Paramita. Jakarta. 
Bring, T., Diesen, C., \& Schelin, L. (1999). Förundersökning [Preliminaryinvestigation]. Stockholm: Nordstedts Juridik. Gish, Mellisa. 2014. E Life We Bury. Retrieved from:http://alleneskens.com. (September 13, 2016)

Creswell (2012). Educational Research: Planning, Conducting, and Evaluating Quantitative and Qualitative Research, $4 e$. Pearson Education.

Departemen Pendidikan Nasional. (2008). Peraturan Menteri Pendidikan Nasional Nomor 27 Tahun 2008 Tentang Standar akademik dan Kompetensi Konselor

Greenwood, P. W., Chaiken, J. M., \& Petersilia, J. (1977). The criminal investigation process. Lexington, MA: Heath.

Kartono. (1999). Patologi Sosial. Jakarta: Raja Grafindo Persada.

R. Soesilo, Taktik dan Teknik Penyidikan Perkara Kriminal, Politeia, Bogor, (1980), h.17

Selian, H., Suhadi, J., \& Manugeren, M. (2017). Heroism in Rudyard Kipling' s The Jungle Book, 1(1), 51-72. https://doi.org/10.30743/11.v1i1.246

Suhartono W. Pranoto. (2008). Bandit Berdasi Korupsi Berjamaah Merangkai Hasil Kejahatan Pasca-Reformasi, Yogyakarta: Penerbit Kanisius.

Taber, K. (2006). Beyond Constructivism: the Progressive Research Programme into Learning Science. Studies in Science Education, 42, 125-184.

Wagenaar, W. A., van Koppen, P. J., \& Crombag, H. F. M. (1993). Anchored narratives: The psychology of criminal evidence. New York: St. Martin's Press. (2002). Undang-Undang Nomor 2 Tahun 2002 tentang Kepolisian Negara Republik Indonesia. 